\title{
Chapter 13 \\ Changes in Climate, Snow and Water Resources in the Spanish Pyrenees: Observations and Projections in a Warming Climate
}

\author{
Enrique Morán-Tejeda, Juan Ignacio López-Moreno \\ and Alba Sanmiguel-Vallelado
}

\begin{abstract}
The Pyrenees constitute one of the greatest sources of freshwater in the Spanish territory, but, like many other mountain systems in the world, they are subject to environmental changes that ultimately affect the availability of water resources in areas downstream. In this study, we offer an assessment of hydrological changes in the Pyrenees, from a warming climate perspective, including climate and snow cover trends, changes in the timing of river flows, and future changes under climate change scenarios. Overall, we found that increasing temperatures are responsible for a lesser accumulation of snow over time, although with spatial differences. As a consequence, the occurrence of spring flows (that largely depend on snowmelt) on the studied rivers, has shifted earlier by approximately one month (from mid-June to mid-May). Future projections, which are made by coupling regional climate models outputs and hydrological modelling, indicate that observed decrease in snow accumulation and shifts in streamflow timing will exacerbate in a warmer short-term future (2050). The amount of water yields will not change significantly, only will suffer a slight decrease due to increased evapotranspiration. Observed and projected hydrological changes must be considered by water managers and environmental technicians if a sustainable management of the water resource and the mountain territory is to be done.
\end{abstract}

Keywords Mountain hydrology - Hydrological changes - Snow cover - River flow $\cdot$ Mountain climate projections

\footnotetext{
E. Morán-Tejeda $(\bowtie)$

Department of Geography, Universitat de Les Illes Balears,

Cra. de Valldemossa, Km 7.5, 07122 Palma (Illes Balears), Spain

e-mail: e.moran@uib.eu
}

\section{J.I. López-Moreno · A. Sanmiguel-Vallelado}

Pyrenean Institute of Ecology, Consejo Superior de Investigaciones Científicas,

Avda. Montañana 1005, 50192 Zaragoza, Spain

J. Catalan et al. (eds.), High Mountain Conservation in a Changing World,

Advances in Global Change Research 62, DOI 10.1007/978-3-319-55982-7_13 


\subsection{Introduction}

Amongst many other ecological functions, mountains play a major role as freshwater reservoirs, this being especially relevant in arid and semi-arid regions (Viviroli et al. 2007). Either in the form of aquifers, lakes, snow or ice cover, the water stored by mountains often represents the principal source of water for most populated areas that are usually located downstream. Thus any process involving changes in the hydrological cycle in the mountains, e.g. in climate variables, land cover, soil properties, or snow cover (Arnell 1999; Foley et al. 2005; Stewart et al. 2005; Bormann et al. 2007; López-Moreno et al. 2011), will have an impact on water availability downstream. Recent observed worldwide warming is inducing environmental changes in high mountains related to their capacity for storing water, including a decrease in the accumulation and accelerated melting of snow, the consequent reduction in the duration of the snowpack, the receding of glaciers and the loss of permafrost (Barnett et al. 2005; Lemke et al. 2007; Adam et al. 2009). Mountains and the process of snow accumulation-melting are hotspots for climate change impacts (Beniston 2003), due to the high sensitivity of the snow cover to seasonal temperatures, especially in low-to-middle elevation sites (Morán-Tejeda et al. 2013). Streamflow, as the ultimate output of mountain systems, will reflect these environmental signals by changing its timing and magnitude, and thus becomes not only a vital resource for populations, but also an important indicator of environmental changes, including global warming, for scientific research.

Climate, snow cover and streamflow are closely connected, and their interactions in high mountain terrains will impact the availability of water for downstream populations. In arid or semi-arid environment, such the Mediterranean, societies have adapted to an irregular availability of water (as a consequence of the high inter-and intra-annual variability of precipitation and temperature) mainly through the construction of dams in mountain valleys for storing water during the periods of water excess, and its release during the high demand and/or low water availability seasons (which are usually coincident). The rapid changes that mountain flows are experiencing, not only due to climate change/variability but also due to land use shifts through afforestation/deforestation and natural land cover expansion (Poyatos et al. 2003), makes it necessary to adapt the water consumption strategies in areas downstream including the management of dams located in mountain valleys (López-Moreno et al. 2004). The assessment of processes involving climate, snow, and hydrology by scientists, at high elevations, must be therefore a key step in planning conservation strategies for mountain territories.

The Pyrenees, located in the transition of Atlantic and Mediterranean climate influences, constitute a paradigmatic example of mountains undergoing rapid changes in environmental conditions, with a potential impact on the availability of water resources for downstream populations. Water availability downstream is highly related to the timing of snow accumulation and snowmelt (López-Moreno 
and García-Ruiz 2004), which is in turn related to the climate variability. The winter snowpack acts as a natural water reservoir that further provides sustained water during spring and summer. The south slopes of the Pyrenees drain to the Ebro River, which flows through a region with semi-arid climatic conditions (low values of precipitation, $\sim 350 \mathrm{~mm} \mathrm{yr}^{-1}$ and large rates of potential evapotranspiration, $\left.\sim 1200 \mathrm{~mm} \mathrm{yr}^{-1}\right)$ but with large irrigation area $\left(9800 \mathrm{~km}^{2}\right)$ and agriculture production, and high populated cities including Zaragoza or Lleida. Thus, the melting waters draining from the Pyrenees are a strategic resource for the economy and development of the downstream region. Moreover, the social development and ecological value of the Pyrenees are highly related to water in solid form. The permanent snowpack during winter months is a major source of economic income for Pyrenean peoples through the touristic industry derived from the practice of ski and other winter sports (Lasanta et al. 2007; Pons et al. 2015).

This work aims to present a general description of the interactions of climate variability/trends, snow cover, and water resources during the last decades in the Pyrenees, as well as to provide a simple but reliable projection in the availability of water resources in the short-term future. For this, we focus our analysis in (1) trends in climate indices that summarize far-from-normal conditions in temperature and precipitation over the mountain chain; (2) temporal trends and spatial variability in snow cover depth over the last decades; (3) changes in the timing of Pyrenean river flows, related to the observed trends in climate indices and snow cover; (4) projection of future changes in river flows by means of hydrological modelling and regional climate models output coupling.

\subsection{Study Area}

The Pyrenees is a mountain range located in SW Europe at the northern edge of the Iberian Peninsula and constitutes the natural border between Spain and France (Fig. 13.1). Altitude within the area ranges from $500 \mathrm{~m}$ to a maximum elevation of $3404 \mathrm{~m}$ a.s.l, and its extension is more than $50,000 \mathrm{~km}^{2}$. The relief is firmly split by the river network due to the disposition of the main valleys (north-south), which are perpendicular to the Pyrenean structures (west-east) (Peña and Lozano 2004).

The climate of the Pyrenees is influenced by its location between the Atlantic Ocean to the west and the Mediterranean Sea to the east. The Central Pyrenees shows a greater Continental influence. Moreover, topographic heterogeneity introduces a noticeable variability to the distributions of precipitation and temperature (Del Barrio et al. 1990; García-Ruiz et al. 2001).

The temperature gradient proposed for the entire Pyrenean range varies according to the author: 0.6 (García-Ruiz et al. 1986), 0.68 (Del Barrio et al. 1990) and $0.63{ }^{\circ} \mathrm{C} / 100 \mathrm{~m}$ (López-Moreno 2006). Based on these gradients, the annual $0{ }^{\circ} \mathrm{C}$ isotherm is located around $2900 \mathrm{~m}$ (Chueca-Cía et al. 2003). However, 

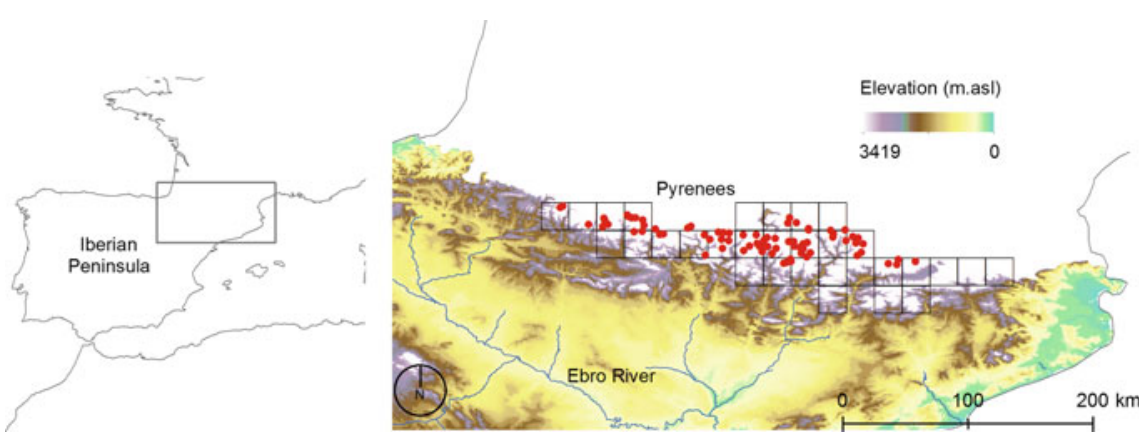

Fig. 13.1 Location of the Pyrenees, with red points indicating the snow poles for snow depth measurements, and square grid indicating the spatial resolution of the climatic database Spain2.0 in the Pyrenean territory (elevation $>1200 \mathrm{~m}$ a.s.l.)

between November and April, it falls at approximately $1600-1700 \mathrm{~m}$ a.s.l. (García-Ruiz et al. 1986), representing the lower limit of the stable winter snow cover. In the mountains, annual precipitation exceeds $2000 \mathrm{~mm}$ and sometimes reaches more than $2500 \mathrm{~mm}$ in the highest divides (García-Ruiz et al. 2001). Most of the annual precipitation falls during the cold season in the western areas, and during spring and autumn in the eastern regions.

Snow depth and duration in the Pyrenees show a marked spatial variability and vertical gradients. There exists a trend towards greater and more prolonged accumulation of snow in areas exposed to Atlantic climatic conditions (westward) compared with areas influenced by Mediterranean conditions (eastward) (López-Moreno et al. 2009). The vertical gradient in accumulated snow is evident, with values ranging between $121 \mathrm{~mm}$ (accumulated snow water equivalent) at $1500 \mathrm{~m}$ a.s.l., and $908 \mathrm{~mm}$ at $3000 \mathrm{~m}$. a.s.l. The duration of snowpack shows a marked increase with altitude, ranging from an average of 50.1 days at $1500 \mathrm{~m}$ to 263.7 days at $3000 \mathrm{~m}$ a.s.l. (López-Moreno et al. 2009).

In general, the timing of snow accumulation and snowmelt markedly modulates the regimes of Pyrenean rivers, as most of the winter precipitation falls as snow in the Pyrenees (López-Moreno and Garcia-Ruiz 2004). Thus flows during winter (December-February) are low and uniform, and flows during spring/beginning of summer (March-July) are greater and have fluctuations (García-Ruíz et al. 1986; Beguería et al. 2003; López-Moreno and García-Ruiz 2004; Bejarano et al. 2010). Regional discharge contrasts have been assessed in relation to basin elevation and the longitudinal climate gradient established in the mountain range (López-Moreno and García-Ruiz 2004). Where large snow accumulation is possible, at the highest and more continental massifs, a delay in the onset of snow melting (mid-April on average) and higher spring flows is usually observed. Downstream the peak spring discharges decrease in intensity and the low winter discharges increase (Beguería et al. 2003). 


\subsection{Data and Methods}

Different types of datasets have been used to accomplish the objectives of this work:

- For studying climate trends and variability, we used the Spain02 database (Herrera et al. 2012), which is a regular $0.2^{\circ}$ latitude/longitude (approximately $20 \mathrm{~km}$ ) daily gridded dataset containing precipitation, maximum and minimum temperatures covering continental Spain and the Balearic Islands during the period 1950-2007. From this, we extracted only pixels located in the Pyrenees range, with an elevation (>1200 m a.s.l.) that ensured the specific climate characteristic of mountains to be captured. A validation of Spain02 against observations shows that temperatures are positively biased (because grid points are generally at lower elevations than the AEMET (Agencia Estatal de Meteorología - the Spanish Meteorological Agency) stations selected for validation). However, this does not affect the computation of trends since the temporal variability of temperature and precipitation is well represented by the gridded dataset $\left(\mathrm{R}^{2}>0.6\right)$.

- Snow thickness measures were provided by the ERHIN program (Evaluación de los Recursos Hídricos procedentes de la Innivación-assessment of water resources from snow) of the Spanish Ministry of Environment. The ERHIN program has been taking snow measurements in the Spanish mountains since mid-1980 with fixed snow poles; three measurements were carried out for every year: the first in late January or early February, the second in March and the third in mid-April or early May. Quality criteria, including a maximum number of three data gaps were set up to obtain reliable snow data series. The data period was set from 1986 (first year of snow sampling) to 2007 (to make it coincide with the last year of the climatic series). Some of the selected series still had few data gaps, and only those with less than $15 \%$ of missing data were filled using the results of linear regressions with the best-correlated series (i.e. those where $\mathrm{R}^{2}>0.7$ ). A total of 84 series of snow depth in April-May, covering most of the Pyrenees area, were finally selected.

- Daily streamflow data was collected from the national water agency of Spain, Centro de Estudios Hidrográficos (CEDEX, http://hercules.cedex.es/anuarioaforos/ default.asp). To make sure that snowmelt pulses were present in all river regimes, we selected only rivers located in the foothills of mountain systems whose drainage watersheds had a mean elevation exceeding 800 m.a.s.l., and had no presence of the reservoirs or impoundment systems upstream of the gauge station. Data from seven gauge stations corresponding to six rivers were finally selected.

Some climatic and hydrological indices were computed in order to capture the conditions that can favour snow accumulation and melt and their signal in the hydrographs.

- The daily resolution of Spain02 database enabled the behaviour of far-from-normal events to be investigated. We computed a series of indices that combine moisture and heat conditions based on the tails of the frequency distributions of daily precipitation and mean temperature series. Based on the frequency distributions of 
precipitation (skewed) and temperature (normal), we selected the 25th and 75th percentiles, and through their combination we obtained four types of days: wet-cold, wet-warm, dry-cold and dry-warm days (Beniston and Goyette 2007). The yearly exceedance series of these joint thresholds were then calculated for winter and spring, and their trends over time were estimated.

- In order to explore changes in the timing of mountain flows, we calculated several indices related to the time of the year when the spring pulse from melting waters is recorded: the day of the maximum spring flows, the day when the 75th percentile of yearly (considering the water year with a start in October 1st) flows is reached, and the day when spring pulse begins (Cayan et al. 2001). By looking at temporal trends in the values of these indices, we can observe if the nival signal of Pyrenean Rivers tended to diminish or augment.

Further, statistical analysis included the computation of correlations using the Pearson's correlation test, the estimation of temporal trends using Mann-Kendall's test and the estimation of patterns in the evolution of hydro-climatic variables using Principal Component Analysis in $\mathrm{S}$ mode.

\subsection{Climate Evolution}

The evolution of climate conditions prone to snow accumulation and melting is depicted in Figs. 13.2 and 13.3. In general, we observe that joint-quantile indices in the Pyrenees show a clear pattern of monotonic trend for the spring season,

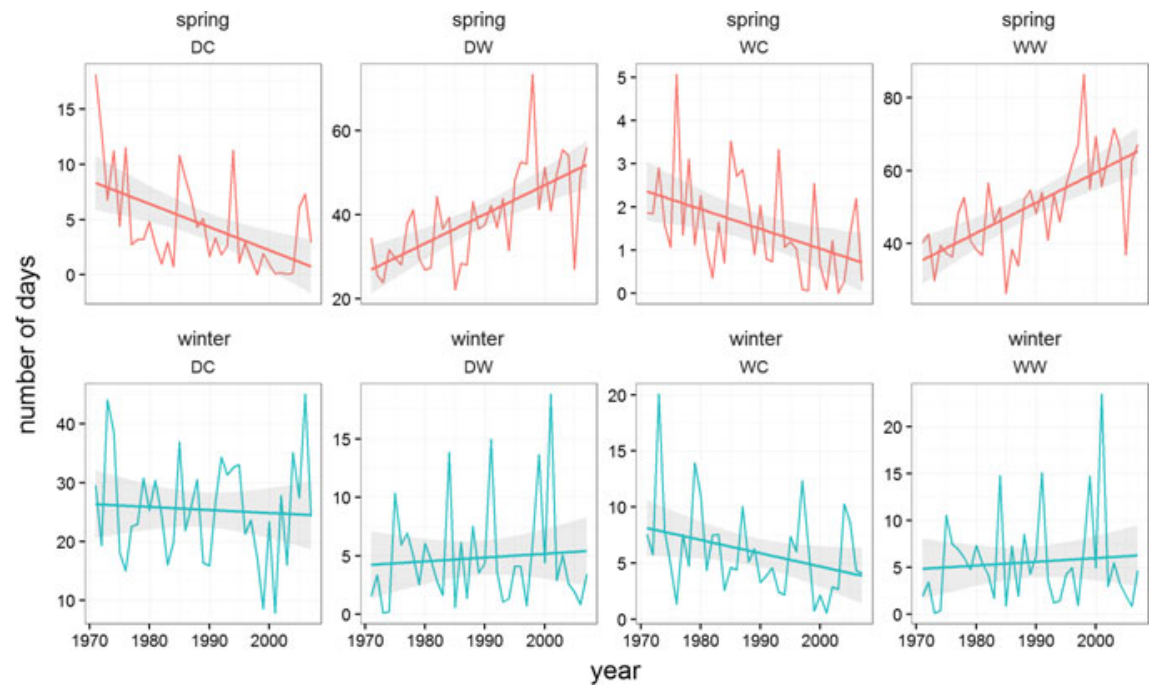

Fig. 13.2 Mean evolution and trend line (shaded area 95\% confidence interval) for joint-quantiles indices in the Pyrenees. $D W$ dry-warm days; $D C$ dry-cold days; $W W$ wet-warm days; $W C$ wet-cold days 

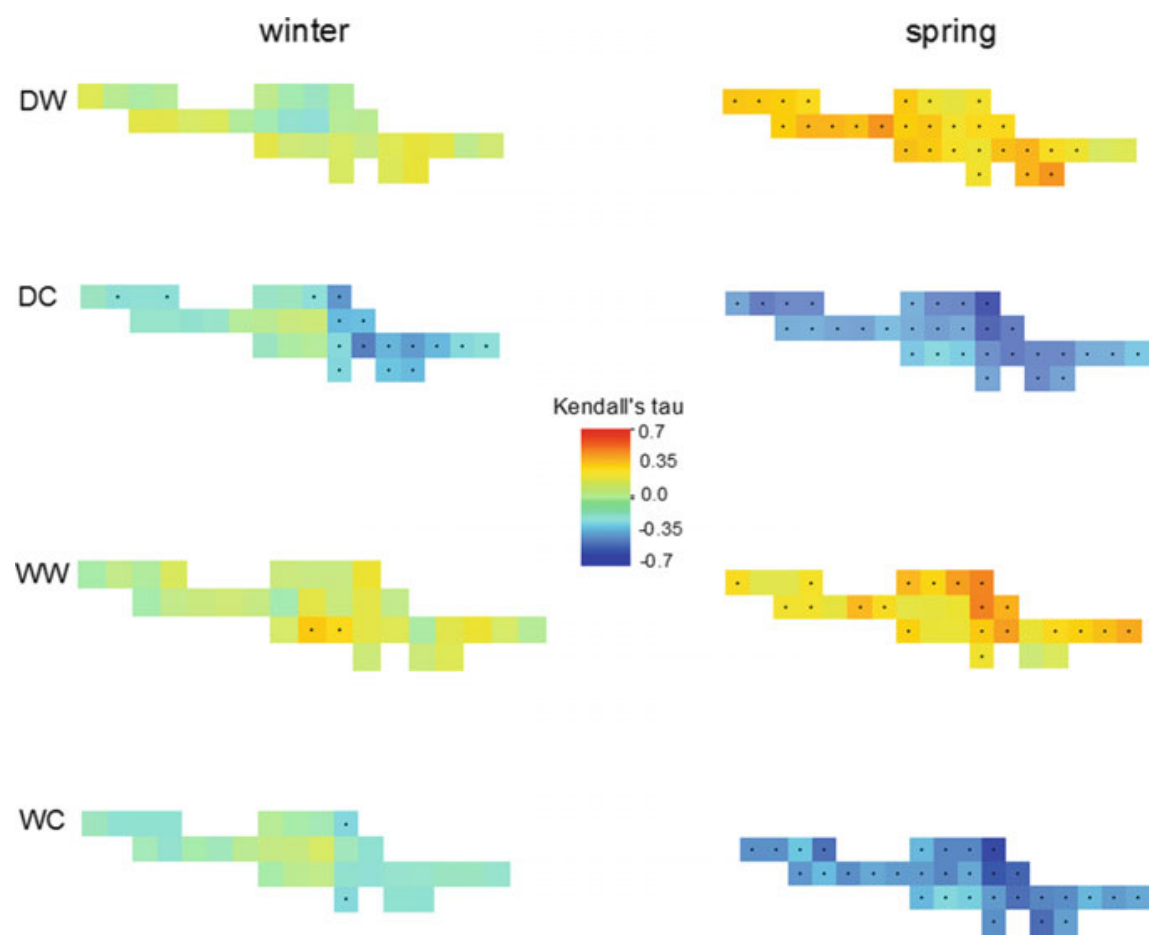

Fig. 13.3 Trends in joint-quantiles indices for the Pyrenean territory. $D W$ dry-warm days; $D C$ dry-cold days; $W W$ wet-warm days; $W C$ wet-cold days. Dots indicate a statistically significant trend with $95 \%$ of confidence

whereas their evolution seems more stationary for winter. The number of dry-cold and wet-cold days in spring show a steep decrease, and the number of dry-warm and wet-warm days show a clear increase. In winter, only wet-cold days show a decrease. When looking at the spatial distribution of trends (Fig. 13.3), we observe that generally, the trends are more pronounced and significant in the east part of the Pyrenees. These plots reveal that far-from-normal temperatures alone are responsible for increasing/decreasing trends in join-quantile indices, whereas far-fromnormal precipitation seems not to have experienced a significant trend during the study period.

We can consider the wet-cold days as the most favourable conditions for snowfalls and the dry-cold days as favourable conditions for snowpack conservation (despite the sublimation that can be caused by intense solar radiation); and their relative warm types as conditions that favour melting or hamper snowpack consolidation. Thus, under such observed trends, it is reasonable to expect a reduction of snowpack in the Pyrenees during the studied period, especially at low elevations, where the zero degrees temperature threshold is reached less often. 


\subsection{Snow Observations}

Figure 13.4 shows the evolution of winter-spring average snow depth (standardiszed values) in the 84 snow poles located across the Pyrenees and the regional average for all the poles. There is a general decrease in snow accumulation, although the trend is not as steep as that observed for climate indices, and is not statistically significant. We must take into account, however, that the length of snow depth series (1984-2007) is not the same as the length of climate series (1950-2007). Given, the high dependency of snow to climate conditions, and the close relation demonstrated between snow depth and temperature/precipitation (López-Moreno 2005; Morán-Tejeda et al. 2013), we can expect that the slight decrease observed for snow depth in the Pyrenees would be sharper if snow data from previous decades (1950-1980) was available. This point was already noted by López-Moreno (2005) when snow series were statistically simulated from temperature and precipitation, showing a statistically significant negative trend for the period 1950-1999. This tendency is in line with the trends observed in other mountain ranges of southern Europe, such as the Alps, where Scherrer et al. (2004), Marty (2008) or Beniston (2012) have also observed a decreasing trend in snow depth and snow duration, especially at low and middle elevation sites.

Although the majority of the snow poles show a similar evolution in the snow depth, there is some dispersion in the data, especially, during the 1985-1995 decade. To search for a relation between the climate indices and the snow depth evolution, we have thus performed a principal component analysis, in which the

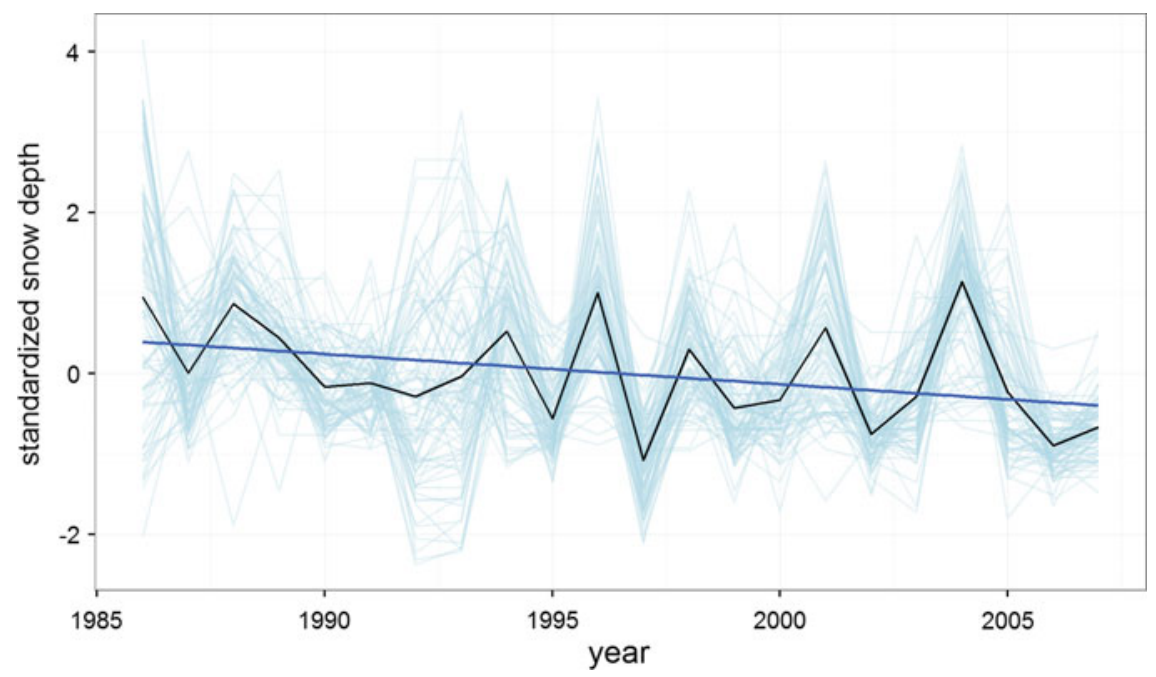

Fig. 13.4 Evolution and trend of winter-spring snow depth across the Pyrenees during the study period. Light blue lines indicate the standardized snow depth in each snow pole and black line indicates the average 
variables to extract the components are the snow poles. Four Principal Components explained $80 \%$ of the variance contained in original data. For representation purposes, we only show the evolution of the two main factors, which together explain $60 \%$ of the variance. The snow depth evolution for each one is depicted in Fig. 13.5a. Thus, we observe two different patterns of evolution in snow depth, though both are showing a decreasing trend. The extraction of principal components enabled us to establish correlations with the join-quantile indices (Fig. 13.5b). For PC1 we observe that significant coefficients are mainly found with index DW

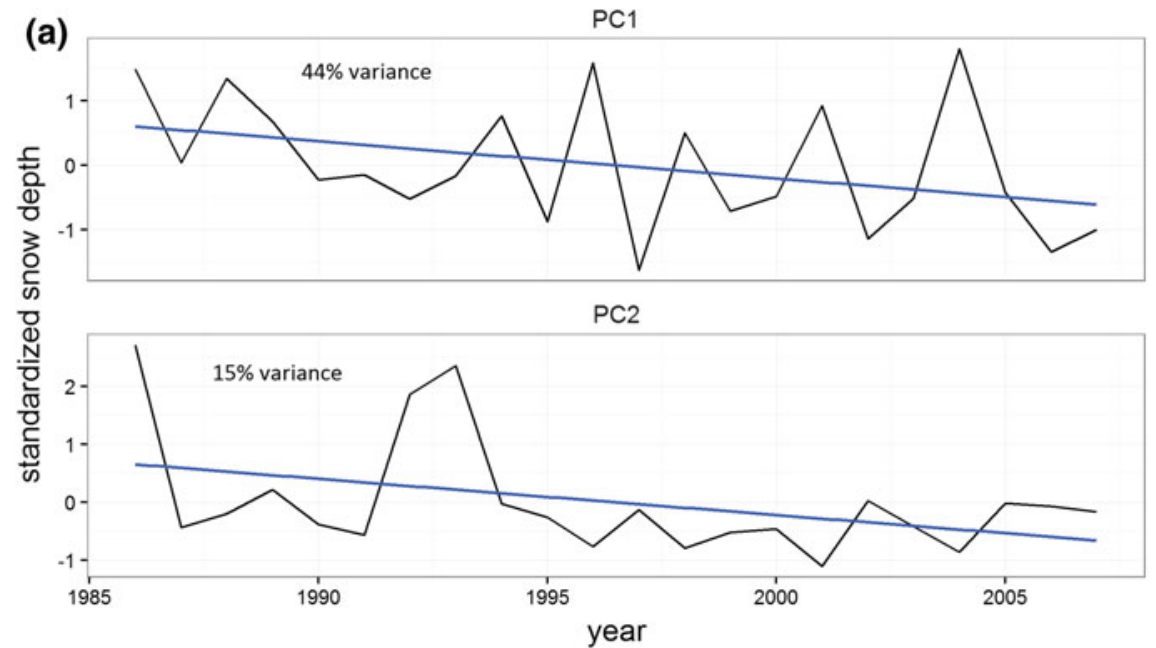

(b) PC1 $\mathrm{PC} 2$

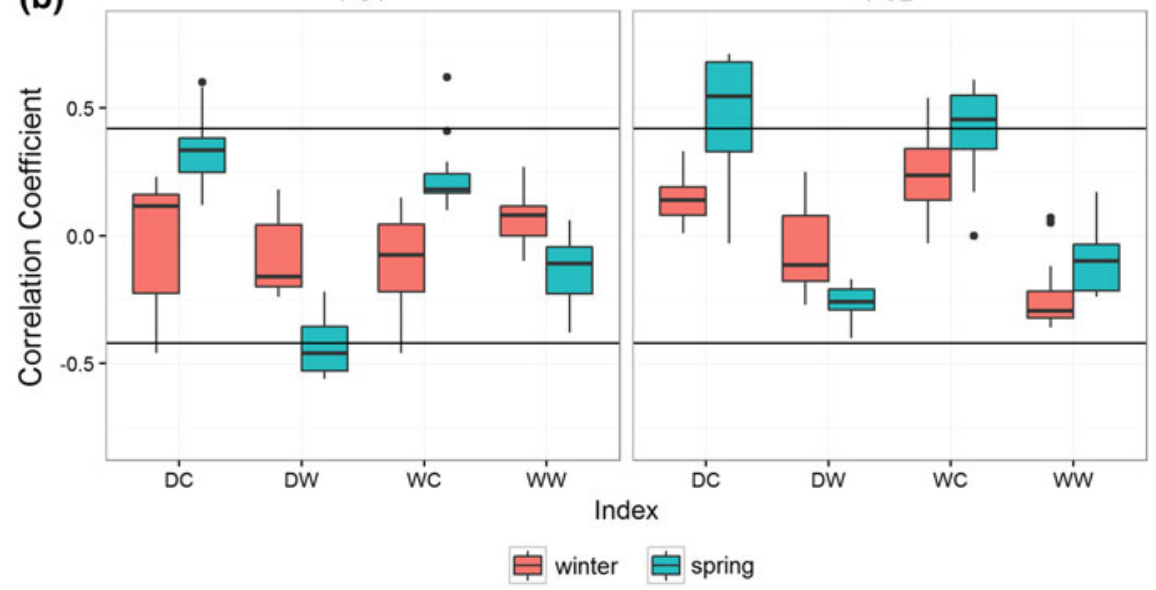

Fig. 13.5 Patterns of snow evolution and explanatory indices. a Evolution of snow depth (standardized) for the two principal components that most variance explained. b Correlations between the climatic indices in each of the pixel for the Pyrenean region and the two principal components depicted in (a) 
for spring, correlations being negative, i.e. the less (more) frequent dry-warm days in spring, the higher (lower) yearly snow accumulation. Thus, this pattern of snow evolution, which is the most frequent, responds inversely to the conditions that hamper snow accumulation and favour snow melting. There are also significant correlations (though less in number) with the number of dry-cold days in spring, thus conditions that favour the conservation of the snowpack. In general, years in which cold days (regardless precipitation) prevail over warm days, are years with higher snow accumulation. It may seem strange that conditions that favour snow accumulation (wet-cold days) do not show a significant explanatory capacity for snow evolution (except for some cases, as can be seen by the dots of the boxplot, which correspond to the 95th and 99th percentiles of the distribution); but this shall be interpreted in terms of limiting conditions: wet-cold days is not a limiting factor for inter-annual snow evolution, meaning that there will still be snowfalls in days that are not extremely cold and particularly wet. In contrary dry-warm days is a strong limiting factor for snowpack consolidation.

PC2 which explains less proportion of variance, and thus represents fewer snow poles, shows a different evolution, and different explanatory variables. The index that best correlates with PC2 is DC in spring, with higher correlations than with $\mathrm{PC} 1$. Thus, in this case, the conditions favourable for snowpack conservation are a limiting factor. But we also found significant correlations with wet-cold days in spring, i.e. with conditions that favour snowfalls and snow accumulation. Contrary to PC1, where conditions that can favour snowfalls were not a limiting factor, in this case, the occurrence of wet-cold days determines whether the year will by more or less snowy.

To find a geographical explanation for the differentiation of PC1 and PC2 and their differing limiting factors, we have performed a Mann-Whitney-Wilcoxon Test, for the following dependent variables: elevation, latitude and longitude. Previously, we separated the snow poles that best correlated with PC1 from the snow poles that best correlated with PC2, and the test was performed over these two populations. Results of the test inform that elevation of snow poles from PC1 is higher $($ mean elevation $=2300 \mathrm{~m}$ ) and differs significantly ( $\mathrm{p}$-value $=0.015)$ from elevation of snow poles from PC2 (mean elevation $=2100$ ). Latitude and longitude did not show significant differences between snow poles of PC1 and PC2 (p values $=0.656$ and 0.657 respectively). This is physically consistent with the fact that cold days were not a limiting factor for snow evolution of PC1, but they were for snow evolution of PC2: the higher is the elevation, the less dependent is snow accumulation to conditions of extreme cold, because the zero degrees isotherm (which marks the limit for snowpack to consolidate) will be reached more frequently. Thus at high elevations, the occurrence of warm days, especially in spring is observed to be the most important limiting factor for the consolidation of the snowpack. Our results suggest that precipitation (absence or particularly high values) is not a factor controlling snowpack variability. This result may be, however, a shortcoming of the joint-quantile indices used. Several studies demonstrated that precipitation can be a good predictor of snowpack variability when used as a single covariate. However, its predictive power depends greatly, on the elevation: 
at low elevations the main climatic snowpack predictor is temperature, but at elevations at which the zero-degree isotherm remains during most of the winter, the variability of precipitation becomes the most important predictor for snowpack variability (López-Moreno 2005; Morán-Tejeda et al. 2013; Sospedra-Alfonso et al. 2015). Thus, it is advisable to interpret elevation-wise, the trends observed in snow depth and snow duration in the context of climate warming. The lack of significant trends observed at high elevations (as observed in this work) do not mean that warming is not affecting the accumulation of snow, but that warming at those elevations is not yet significant enough as to affect snow accumulation. Further warming projected by climate models will, however, make increase the elevation threshold at which temperatures become a limiting factor for snow accumulation, and negative trends in snowpack depth and duration will be more likely found at increasing elevations (Morán-Tejeda et al. 2013).

\subsection{Streamflow Changes}

To study for hydrological changes, we selected three Pyrenean Rivers (Ésera, Aragón and Ara Rivers) with natural flow regimes (unaffected by dams or water extractions) and we further defined three indices that represent different moments of the year related to the signal of snow on the hydrograph (Fig. 13.6). SP indicates the day of the year when the streamflow pulse due to snow melting starts (see calculation in Cayan et al. 2001); SM stands for the day of the year when the maximum spring flow is reached; and $75 \mathrm{M}$ indicates the day of the year when the 75 th percentile of yearly water volume is reached. After these indicators had been computed for every year in each of the three selected rivers, we checked the existence of trends in time using Mann-Kendall and Thiel-Sen's slope estimator tests (Table 13.1). The three indices show a decreasing trend for the three selected

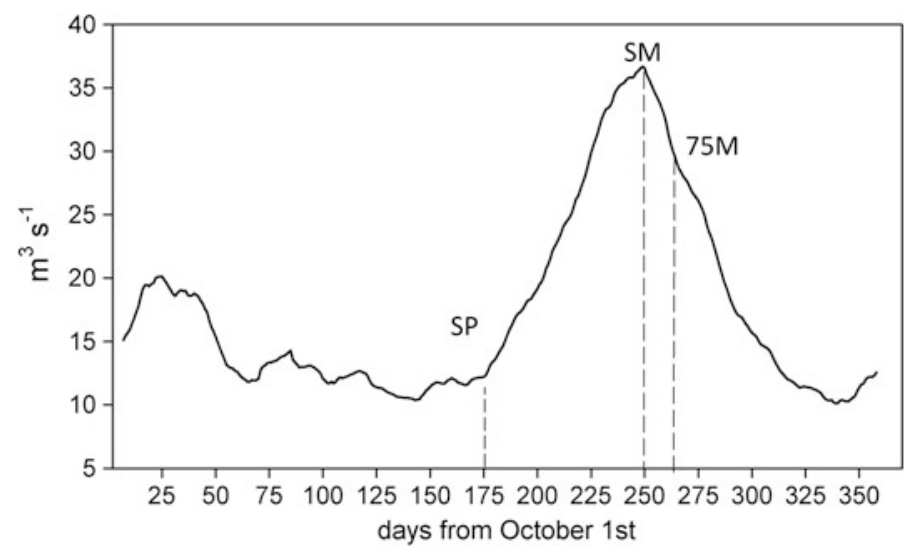

Fig. 13.6 Example of location of hydrological indices across a yearly hydrograph 
Table 13.1 Trend statistics for SP, MS and $75 \mathrm{M}$ hydrological indices

\begin{tabular}{l|l|l|l|l}
\hline Index & Trend statistic & Ésera & Aragón & Ara \\
\hline \multirow{4}{*}{ SP } & Slope & -0.65 & -0.34 & -0.64 \\
\cline { 2 - 5 } & Change & -24.7 & -11.2 & -21.3 \\
\cline { 2 - 5 } & Tau & -0.15 & -0.07 & -0.18 \\
\cline { 2 - 5 } & Sig & 0.21 & 0.54 & 0.16 \\
\hline \multirow{4}{*}{ MS } & Slope & -0.48 & -1.13 & -1.0 \\
\cline { 2 - 5 } & Change & -27.8 & -37.6 & -33 \\
\cline { 2 - 5 } & Tau & -0.4 & -0.38 & -0.47 \\
\cline { 2 - 5 } & Sig & 0.001 & 0.002 & 0.0013 \\
\hline $75 M$ & Slope & -0.57 & -0.58 & -0.6 \\
\cline { 2 - 5 } & Change & -18.3 & -18.5 & -19.2 \\
\cline { 2 - 5 } & Tau & -0.32 & -0.3 & -0.36 \\
\cline { 2 - 5 } & Sig & 0.01 & 0.015 & 0.004 \\
\hline
\end{tabular}

Slope Theil-Sen's slope estimator; change change in the number of days over the study period; tau = correlation coefficient for the Mann-Kendall's test; sig p-value for the test

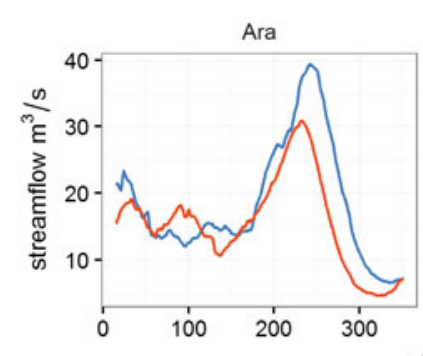

days from October $1^{\text {st }}$ (hydrological year)
$-1976-1992-1993-2009$

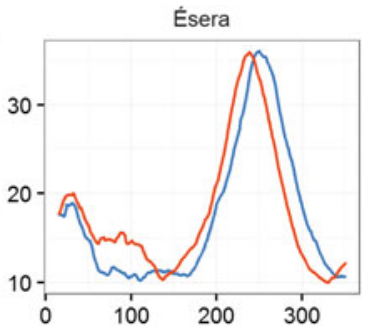

Fig. 13.7 Changes in the hydrograph of Pyrenean Rivers during the study period

rivers, although trends for SP are not significant with a 95\% confidence level. Trends in the other two indices are statistically significant: the day when maximum spring flows are reached occurs now a month earlier and the day when the 75th percentile of the yearly streamflow is reached occurs nearly 20 days earlier.

In Fig. 13.7 we can visualize the results of the trends above, in simple plots that represent the average hydrograph of rivers for the first and second halves of the study period. In the three cases, we readily observe that nowadays there is an earlier occurrence of the spring peak, which results from snow melting, than some decades ago; with the correspondent increase in winter flows. In our view, this is the reaction of the hydrological system, to the changes in climate and snow accumulation discussed in previous paragraphs.

With the aim of verifying it, we have computed correlations between the evolution of each hydrological index and the evolution of different seasonal/annual 


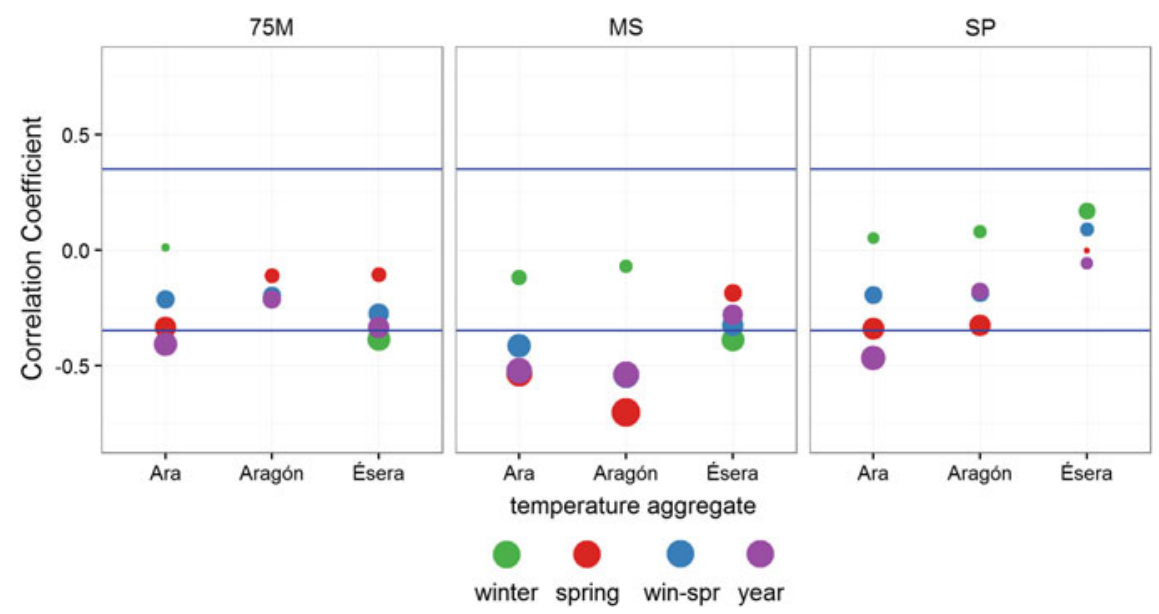

Fig. 13.8 Pearson correlations between hydrological indices and temperature aggregates for the three studied rivers. Circle size is proportional to the correlation level. Blue horizontal lines indicate significant level set at $95 \%$ of confidence

temperature aggregates (winter, spring, winter-spring and year averages) (Fig. 13.8). Generally, there are negative correlations between the hydrological indices and the temperatures, although some temperature aggregates are a better predictor than others. The hydrological index best explained by temperature evolution is MS, especially in Aragon and Ara Rivers, where average spring temperatures and annual average temperatures show correlation values close to $\mathrm{R}=-0.7$. Indices $75 \mathrm{M}$ and SP show lower correlations coefficients, but still significant in Ara River for annual and average spring temperature. These results confirm that, although others factors (e.g. variability in seasonal precipitation) may greatly affect the timing of river flows in snow-fed rivers (Sanmiguel-Vallelado et al. 2017), there is a clear correspondence between the observed increase in temperature and the early occurrence of the spring peak in Pyrenean rivers. This process in not exclusive of the Pyrenees, and has been observed in rivers of snow-dominated regions around the globe, including the Rocky Mountains (Stewart et al. 2005), or New England (Hodgkins et al. 2003) in the United Sates, or the Swiss Alps in Europe (Birsan et al. 2005). The underlying processes behind these trends are the decrease in the snowfall/rainfall ratio in winter and the earlier snowmelt in spring due to higher temperatures.

\subsection{Projections for a Warmer Climate}

The observed correspondence between trends in temperature and changes in streamflow timing make it logical to expect that further climate warming due to the increase in the atmospheric concentration of greenhouse gases (IPCC 2013), 
will enhance further hydrological changes. In recent years, a great effort has been made by hydrological scientists to provide reliable projections of future water resources availability in a warmer climate by coupling climate and hydrological models. In this last section, we aim to provide a simple, but feasible, projection of future changes in streamflow of Pyrenean Rivers through a hydrological modelling approach, considering climate warming scenarios. The hydrological simulations were done with SWAT (Soil Water Assessment Tool) model, for the Ésera River, considering the changes in temperature (delta changes) that the Regional Climate Models of the ENSEMBLES project (Hewitt and Griggs 2004), predict for the time window 2035-2065, compared to the control period 1970-2000. We did not consider changes in precipitation due to the high level of uncertainty related to precipitation projections for the future. Details on the model calibration and climate scenarios can be found in Morán-Tejeda et al. (2015). Figure 13.9 shows a summary of results, considering the multi-model 10th percentile, average and 90th percentile temperature projections (Table 13.2). The left plot shows the changes in snow water equivalent (SWE), i.e. the volume of water contained in the snowpack, yearly and monthly (lines). Decrease in SWE is evident in warming conditions with nearly $-45 \%$ considering the multi-model average. SWE decrease is consistent throughout the entire snow season but is even greater in spring (around Julian day 180-200). As a result of the warming, the duration of the snowpack will be as well reduced an average of 50 days. The hydrological result is depicted in Fig. 13.9 (right plot). We thus observe a very small decrease in annual water yield of $-1,9 \%$ for the multi-model average (mainly due to an increase in evapotranspiration), but a significant change in the timing of flows. Spring and summer flow (from May to September) will experience a substantial decrease, but it will be compensated by an increase in winter flows. Overall, the hydrograph would experience a sort of smoothing, with less marked seasonality. This feature would potentially involve changes in water management to satisfy water demands in downstream areas.

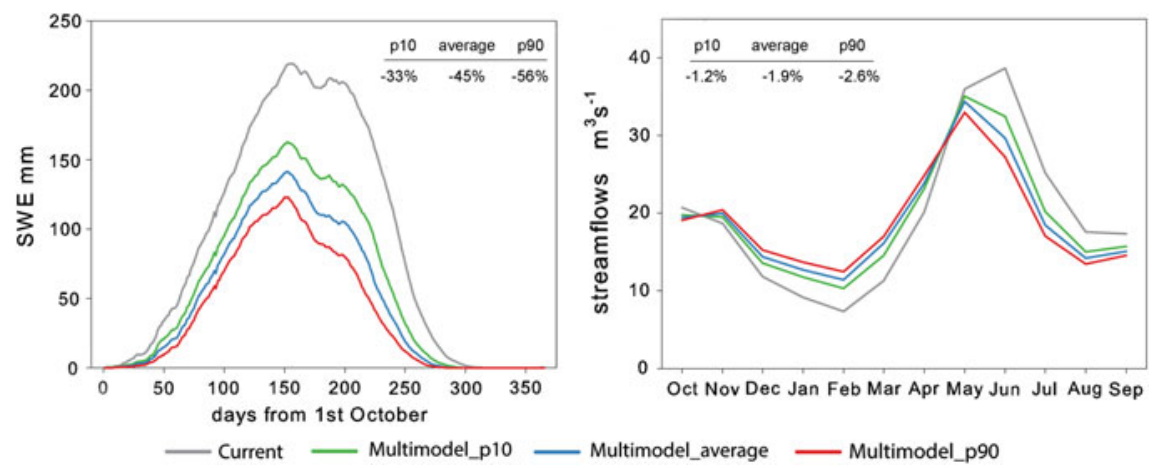

Fig. 13.9 Monthly (lines) and yearly (text) changes in snow water equivalent (SWE) (left plot) and in streamflows (right plot), projected by SWAT model for the Ésera river, under climate change conditions 
Table 13.2 Temperature changes $\left({ }^{\circ} \mathrm{C}\right)$ projected by RCMs of ENSEMBLES project for 2035-2065 in our study area

\begin{tabular}{l|l|l|l|l}
\hline & Winter & Spring & Autumn & Summer \\
\hline p10 & +1.2 & +1.2 & +1.9 & +1.8 \\
\hline Average & +1.7 & +1.8 & +2.7 & +2.2 \\
\hline p90 & +2.1 & +2.5 & +3.8 & +2.6 \\
\hline
\end{tabular}

As noted above, many reservoirs store water from Pyrenean rivers to supply water during the season of lower availability and higher demand (summer). As observed by López-Moreno et al. (2004), Pyrenean reservoirs have used different patterns of management (basically two) during the last decades, but in a very restricted way, not adapted to the inter-annual variability of river flows. We want to emphasize on the recommendation done by López-Moreno et al. (2004) for a more dynamic management of Pyrenean reservoirs, given the occurred changes in river flows and their possible enhancement during next decades.

Although we did not consider changes in future amounts of precipitation, climate models predict that it is likely to experience a decrease during the 21 st century in the Mediterranean region (Giorgi and Lionello 2008). If such predictions are right, we would have to add a decline in streamflow amounts to the observed change in the timing of flows. Another process that was not considered here may involve a further reduction in water availability. The Pyrenees, as many other Spanish mountains are experiencing a recovery of natural vegetation, including shrubs and forests, due to the abandonment of traditional activities that used the mountain slopes for pastures and cropping (Vicente-Serrano et al. 2004; Lasanta-Martínez et al. 2005). It has been experimentally demonstrated that forested catchments yield less amount of water than non-forested ones (e.g. García-Ruiz et al. 2008) due to rainfall interception and evapotranspiration by forest canopy (Llorens and Domingo 2007). Hydrological modelling also shows that future increase of vegetation cover in Pyrenean catchments would reduce river flows (López-Moreno et al. 2014). This aspect involves more complexity and uncertainty for the prediction of future water resources availability, but also gives us key information for improving the management of water in the Pyrenees in a more integrated fashion.

\subsection{Conclusions}

We show in this work a comprehensive analysis of the evolution of climate, snow cover and water resources in the Spanish Pyrenees, during the last four decades, and the interactions amongst them. This analysis has been possible due to the existence of quality databases of precipitation, temperature, snow depth and streamflows developed and managed by different institutions.

Climatically, we focused on the tails of the climate variables distributions, to find any trend in conditions that could favour/hamper snow accumulation and melting. We found a decrease in the number of dry-cold and wet-cold days, and an increase in the number of warm-dry and warm-wet days, meaning that only far-from-mean temperatures and not precipitation, have experienced significant trends. 
Snow depth evolution in the Pyrenees shows spatial variability, but overall we observed a negative trend of snow depth during the study period. Moreover, we found that in the snow depth sites located at higher elevations (2100-2600 m a.s.l.), snow variability correlated inversely with the frequency of dry-warm days in spring, indicating that only in years when exceptionally warm days predominate, snowpack will be reduced, whereas the frequency of cold days is not a limiting factor. On the contrary, in snow measurement sites at lower elevations (1800-2400 m a.s.1.), snow variability correlated with the frequency of dry-cold and wet-cold days in spring, meaning that spring temperature begins to be a limiting factor at this lower sites.

The consequence of the above mentioned trends over water resources has been, so far, a change in the timing of flows, particularly on the occurrence of the spring peak that results from snowmelt. On the studied rivers, there is an earlier occurrence of spring flows during recent years than four decades ago. The increase of spring temperatures triggers an earlier snowmelt, an overall decrease in the duration of the snowpack and an earlier and lower spring peak flow. When projecting future hydrological changes by coupling RCMs outputs and hydrological modelling, we observe that the detected changes are likely to be enhanced if temperatures grow as estimated by climate models: winter flows will augment due to fewer snowfalls and snow accumulation and consequently spring flows will decrease. The amount of water resources available will not suffer big changes, except if a large decrease in precipitation occurs.

Such changes must be acknowledged by water managers and water users from downstream territories and incorporated in long-term water management policies that promote a sustainable use of the water resource in this sensitive territory.

\section{References}

Adam JC, Hamlet AF, Lettenmaier DP (2009) Implications of global climate change for snowmelt hydrology in the twenty-first century. Hydrol Process 23:962-972

Arnell NW (1999) The effect of climate change on hydrological regimes in Europe: a continental perspective. Glob Environ Chang-Hum Policy Dimens 9:5-23

Barnett TP, Adam J, Lettenmaier DP (2005) Potential impacts of a warming climate on water availability in snow-dominated regions. Nature 438:303-309

Beguería S, López-Moreno JI, Lorente A, Seeger M, García-Ruiz JM (2003) Assessing the effect of climate oscillations and land-use changes on streamflow in the Central Spanish Pyrenees. Ambio 32:283-286

Bejarano MD, Marchamalo M, de Jalón DG, del Tánago MG (2010) Flow regime patterns and their controlling factors in the Ebro basin (Spain). J Hydrol 385:323-335

Beniston M (2003) Climatic change in mountain regions: a review of possible impacts. Clim Change 59:5-31

Beniston M (2012) Is snow in the Alps receding or disappearing?, WIREs climate change (wiley interdisciplinary reviews/climate change). doi:10.1002/wcc.179

Beniston M, Goyette S (2007) Changes in variability and persistence of climate in Switzerland: exploring 20th century observations and 21st century simulations. Glob Planet Chang 57:1-15

Birsan MV, Molnar P, Burlando P, Pfaundler M (2005) Streamflow trends in Switzerland. J Hydrol 314:312-329 
Bormann H, Breuer L, Gräff T, Huisman JA (2007) Analysing the effects of soil properties changes associated with land use changes on the simulated water balance: a comparison of three hydrological catchment models for scenario analysis. Ecol Model 209:29-40

Cayan DR, Dettinger MD, Kammerdiener SA, Caprio JM, Peterson DH (2001) Changes in the onset of spring in the western United States. Bull Am Met Soc 82:399-415

Chueca-Cía J, Julian-Andrés AMA, López-Moreno JI (2003) Variations of Glaciar Coronas, Pyrenees, Spain, during the 20th century. J Glaciol 49:449-455

Del Barrio G, Creus J, Puigdefábregas J (1990) Thermal seasonality of the high mountains belt of the Pyrenees. Mount Res Dev 10:227-233

Foley JA, DeFries R, Asner GP, Barford C, Bonan G, Carpenter SR, Chapin FS, Coe MT, Daily GC, Gibbs HK, Helkowski JH, Holloway T, Howard EA, Kucharik CJ, Monfreda C, Patz JA, Prentice I, Ramankutty N, Snyder PK (2005) Global consequences of land use. Science 309:570-574

García-Ruiz JM, Puigdefábregas TJ, Creus-Novau J (1986) La acumulación de nieve en el Pirineo Central y su influencia hidrológica. Pirineos 127:27-72

García-Ruiz JM, Beguería S, López-Moreno JI, Lorente A, Seeger M (2001) Los recursos hídricos superficiales del Pirineo aragonés y su evolución reciente. Geoforma, Logroño, p 192

García-Ruiz JM, Regüés D, Alvera B, Lana-Renault N, Serrano-Muela P, Nadal-Romero E, Navas A, Latron J, Martí-Bono C, Arnáez J (2008) Flood generation and sediment transport in experimental catchments affected by land use changes in the central Pyrenees. J Hydrol 356:245-260

Giorgi F, Lionello P (2008) Climate change projections for the Mediterranean region. Glob Planet Change 63:90-104

Herrera S, Gutiérrez JM, Ancell R, Pons MR, Frías MD, Fernández J (2012) Development and analysis of a 50-year high-resolution daily gridded precipitation dataset over Spain (Spain02). Int J Climatol 32(1):74-85

Hewitt CD, Griggs DJ (2004) Ensembles-based predictions of climate changes and their impacts (ENSEMBLES). Eos 85:566

Hodgkins GA, Dudley RW, Huntington TG (2003) Changes in the timing of high river flows in New England over the 20th century. J Hydrol 278:244-252

IPCC (2013) Climate change 2013: the physical science basis. Contribution of working group I to the fifth assessment report of the intergovernmental panel on climate change In: Stocker, T.F., D. Qin, G.-K. Plattner, M. Tignor, S.K. Allen, J. Boschung, A. Nauels, Y. Xia, V. Bex and P. M. Midgley (eds). Cambridge University Press, Cambridge, United Kingdom and New York, NY, USA

Lasanta-Martínez T, Vicente-Serrano SM, Cuadrat-Prats JM (2005) Mountain Mediterranean landscape evolution caused by the abandonment of traditional primary activities: a study of the Spanish Central Pyrenees. Appl Geogr 25:47-65

Lasanta T, Laguna M, Vicente-Serrano SM (2007) Do tourism-based ski resorts contribute to the homogeneous development of the Mediterranean mountains? A case study in the Central Spanish Pyrenees. Tourism Manag 28:1326-1339

Lemke P, Ren J, Alley RB, Allison I, Carrasco J, Flato G, Fujii Y, Kaser G, Mote P, Thomas RH, Zhang T (2007) Observations: changes in snow, ice and frozen ground, climate change 2007: The physical science basis. Contribution of working group i to the fourth assessment report of the intergovernmental panel on climate change. In: Solomon S, Qin D, Manning M, Chen Z, Marquis M, Averyt KB, Tignor M, Miller HL (eds) Cambridge University Press. UK, Cambridge, pp 337-383

Llorens P, Domingo F (2007) Rainfall partitioning by vegetation under Mediterranean conditions. A review of studies in Europe. J Hydrol 335:37-54

López-Moreno JI (2005) Recent variations of snowpack depth in the Central Spanish Pyrenees. Arct Antarct Alp Res 37:253-260

López-Moreno JI (2006) Cambio ambiental y gestión de embalses en el Pirineo Central Español. Consejo de Protección de la Naturaleza de Aragón, Zaragoza 
López-Moreno JI, García-Ruiz JM (2004) Influence of snow accumulation and snowmelt on streamflow in the central Spanish Pyrenees/Influence de l'accumulation et de la fonte de la neige sur les écoulements dans les Pyrénées centrales espagnoles. Hydrol Sci J 49(5)

López-Moreno JI, Beguería S, García-Ruiz JM (2004) The management of a large Mediterranean reservoir: storage regimens of the Yesa reservoir, upper Aragon river basin, central Spanish Pyrenees. Environ Manag 34:508-515

López-Moreno JI, Goyette S, Beniston M (2009) Impact of climate change on snowpack in the Pyrenees: horizontal spatial variability and vertical gradients. J Hydrol 374:3-4

López-Moreno JI, Vicente-Serrano SM, Morán-Tejeda E, Zabalza J, Lorenzo- Lacruz J, García-Ruiz JM (2011) Impact of climate evolution and land use changes on water yield in the Ebro basin. Hydrol Earth Syst Sci 15:311-322

López-Moreno JI, Zabalza J, Vicente-Serrano SM, Revuelto J, Gilaberte M, Azorin-Molina C, Morán-Tejeda E, García-Ruíz JM, Tague C (2014) Impact of climate and land use change on water availability and reservoir management: scenarios in the Upper Aragón River, Spanish Pyrenees. Sci Total Environ 493:1222-1231

Marty C (2008) Regime shift of snow days in Switzerland. Geophys Res Lett 35:L12501

Morán-Tejeda E, López-Moreno JI, Beniston M (2013) The changing roles of temperature and precipitation on snowpack variability in Switzerland as a function of altitude. Geophys Res Lett 40:2131-2136

Morán-Tejeda E, Zabalza J, Rahman K, Gago-Silva A, López-Moreno JI, Vicente-Serrano S, Lehmann A, Tague C, Beniston M (2015) Hydrological impacts of climate and land-use changes in a mountain watershed: uncertainty estimation based on model comparison. Ecohydrology 8:1396-1416

Peña J, Lozano M (2004) Las unidades del relieve aragonés, Geografía Física de Aragón, Aspectos Generales y Temáticos. Universidad de Zaragoza, Zaragoza

Pons M, López-Moreno JI, Rosas-Casals M, Jover È (2015) The vulnerability of Pyrenean ski resorts to climate-induced changes in the snowpack. Clim Change 131:591-605

Poyatos R, Latron J, Llorens P (2003) Land use and land cover change after agricultural abandonment: the case of a Mediterranean mountain area (Catalan Pre-Pyrenees). Mount Res Dev 23:362-368

Sanmiguel-Vallelado A, Morán-Tejeda E, Alonso-González E, López-Moreno JI (2017) Effect of snow on mountain river regimes: an example from the Pyrenees. Front Earth Sci 1-16

Scherrer SC, Appenzeller C, Laternser M (2004) Trends in Swiss Alpine snow days: the role of local- and large-scale climate variability. Geophys Res Lett 31:L13215

Sospedra-Alfonso R, Melton JR, Merryfield WJ (2015) Effects of temperature and precipitation on snowpack variability in the Central Rocky Mountains as a function of elevation. Geophys Res Lett 42:4429-4438

Stewart IT, Cayan DR, Dettinger MD (2005) Changes toward earlier streamflow timing across western North America. J Clim 18:1136-1155

Vicente-Serrano SM, Lasanta T, Romo A (2004) Analysis of spatial and temporal evolution of vegetation cover in the Spanish Central Pyrenees: role of human management. Environ manag 34:802-818

Viviroli D, Dürr HH, Messerli B, Meybeck M, Weingartner R (2007) Mountains of the world, water towers for humanity: typology, mapping, and global significance. Water Resour Res 43. doi:10.1029/2006WR005653 
Open Access This chapter is licensed under the terms of the Creative Commons Attribution 4.0 International License (http://creativecommons.org/licenses/by/4.0/), which permits use, sharing, adaptation, distribution and reproduction in any medium or format, as long as you give appropriate credit to the original author(s) and the source, provide a link to the Creative Commons license and indicate if changes were made.

The images or other third party material in this chapter are included in the chapter's Creative Commons license, unless indicated otherwise in a credit line to the material. If material is not included in the chapter's Creative Commons license and your intended use is not permitted by statutory regulation or exceeds the permitted use, you will need to obtain permission directly from the copyright holder.

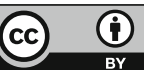

